Research Article

\title{
Proportion of smokers and its determinants among migrant workers in Mysore, Karnataka, India
}

\author{
Amrutha AM, Aravind Karinagannanavar*, Mansoor Ahmed
}

Department of community medicine, Mysore Medical College and Research Centre, Mysore, Karnataka, India.

Received: 26 January 2016

Accepted: 03 March 2016

*Correspondence:

Dr. Aravind Karinagannanavar

E-mail: draravindmbbs5@gmail.com

Copyright: ( $\odot$ the author(s), publisher and licensee Medip Academy. This is an open-access article distributed under the terms of the Creative Commons Attribution Non-Commercial License, which permits unrestricted non-commercial use, distribution, and reproduction in any medium, provided the original work is properly cited.

\section{ABSTRACT}

Background: The World Health Organization (WHO) estimated that about 4 million deaths worldwide annually are attributable to tobacco use. There are more than 20 million of construction workers in India at present. The unhygienic situation, working pattern, absence of any recreational activity and company of friends force them to indulge in various abuse activities. The objective of the studies was proportion of smokers in migrant workers in Mysore city and to know the determinants of smoking among migrant workers in Mysore city, India.

Methods: A cross-sectional study design was conducted among 375 migrant workers in Mysore city, from 01.08.2105 to 01.10.2015. "Direct interview method" of primary source of information technique was used for data collection. A pre-tested semi-structured was used to meet the objectives of the study.

Results: The overall proportion of smokers was 35\%. The mean age of initiation of smoking was 20.35 years and the reason was peer pressure, duration of smoking was 12.46 years. $46 \%$ of smokers had intention to quit smoking, others gave a reason as addiction (67.2\%) for not quitting. Significant association was found between tobacco use and socioeconomic parameters such as age group, marital and socio economic status. It was also found that workers who were migrants for more than 20 years had significantly higher proportions of smokers.

Conclusions: The proportion of smokers was $36.2 \%$.Significant determinants of smoking were those aged more than 40 years, those of lower socio economic status, those married and more than 20 years as a migrant worker.

Keywords: Smoking pattern, Determinants of Smoking, Migrant workers

\section{INTRODUCTION}

The World Health Organization has identified tobacco smoking and binge alcohol drinking as two of the leading risk factors for premature mortality worldwide. ${ }^{1,2}$ In India, $14 \%$ per cent of the population above age 15 smoke tobacco (24\% for men and 3\% for women). ${ }^{3}$ Smoking is already responsible for about 1 in 5 deaths for men and 1 in 20 deaths for women at ages 30-69. ${ }^{4}$ There are currently about 1.1 billion smokers in the world, $70 \%$ of whom are in low-income countries. There are estimates that over the next 50 years, 450 million may die because of tobacco use. ${ }^{5}$ An estimated 150 million of the young people use tobacco. ${ }^{6}$ The World Health Organization (WHO) estimated that about 4 million deaths worldwide annually are attributable to tobacco use, a number expected to more than double by $2030 .^{7}$ Tobacco related deaths are increasing in India, and account for approximately a sixth of the world's tobacco related deaths. It is expected that by the year 2030 about $80 \%$ of these deaths will be in developing countries. ${ }^{8}$ Smoking is responsible for a large number of premature deaths in India. The majority of smoking related deaths in India occur in the prime working age group of 15-59 years. ${ }^{9}$ In India tobacco consumption in various forms is the single most important avoidable factor in the growth of non-communicable diseases. It has also been observed that the Tobacco demand in India has remained high and has shown no signs of declining. The 52nd round of the NSS on Morbidity and Private Health Expenditure, 
conducted between June 1995 and June 1996 by the National Sample Survey Organization (NSSO) of the Government of India, collected information on current regular smoking and chewing of tobacco for all individuals aged 10 years and above. The survey estimated tobacco use prevalence among males to be at $51.3 \%$ and among females at $10.3 \% .^{8}$

Construction sector is ever growing industry. The construction industry has registered enormous growth worldwide during last few decades. There are more than 20 million of construction workers in India at present. Migration from different states to other states in India has now become so rampant that its impact is felt in every aspect of life. Very few studies have explored the problems of construction workers even though they are more susceptible to various myriad of occupational hazards. Majority of employees in the construction sector are aged between 15 and 45, live in single sex quarters, and migrate to their place of work. Hence, tobacco and alcohol abuse or other risk-taking behavior is quite common in any area of this sector. ${ }^{9}$ Workers in this industry need to do heavy physical work while living in shabby environment. The unhygienic situation, working pattern, absence of any recreational activity and company of friends force them to indulge in various abuse activities.

There are many misconceptions regarding the tobacco and alcohol, that it helps increase concentration, suppresses appetite, reduces anxiety and tension, causes skeletal muscle relaxation and induces feeling of pleasure. With this background an attempt is made.

The objective of the studies was proportion of smokers in migrant workers in Mysore city and to know the determinants of smoking among migrant workers in Mysore city, India.

\section{METHODS}

To assess the proportion of smokers and determinants of smoking among the construction workers, a crosssectional study design was chosen and the maximum inflated sample size is 363 rounded off to 375 , which is calculated using estimation technique with prevalence of smoking in migrants as $21.6 \%$ with $5 \%$ level of significance and precision $20 \% .^{10}$ The sampling frame considered for the study was all migrant sites in Mysore city during the study period $6^{\text {th }}$ January, 2015 to $31^{\text {st }}$ July, 2015. Simple random technique was used for selection of construction sites and in those sites all the eligible workers were considered for the study. Construction sites were selected till the required sample size was met. "Direct interview method" of primary source of information technique was used for data collection. Informed written consent was obtained from each study subject. A pre-tested semi-structured and structured questionnaire was used to meet the objectives of the study. An inclusion criterion was all migrant construction workers who give consent.

\section{RESULTS}

Socio-demographics: out of 375 workers, majority were males $(77 \%)$ nearly half $(51.2 \%)$ workers belonged to the age group of 21-39 years. The mean age of workers was 30 years. $78 \%$ of the workers were unmarried, most of the workers $(97 \%)$ were following hindu religion. Nearly $63 \%$ workers were illiterate. Out of 375 migrants, majority (34\%) of workers had migrated from Andhra Pradesh, followed by West Bengal (17.8\%) and Orissa $(10.4 \%)$ (Table 1). most of them stayed within premises of construction site. The mean working hours per day is 10.22 hours. The mean years as a migrant worker was 6.54 years mean number of migrant states travelled were 2.7.majority had no night shift (79.8\%).

Table 1: Socio-demographic profile of the study subjects.

\begin{tabular}{|c|c|c|}
\hline Parameters & Subcategory & $\begin{array}{l}\text { No. of workers }(\%) \\
N=375\end{array}$ \\
\hline \multirow{3}{*}{$\begin{array}{l}\text { Age group } \\
\text { (years) }\end{array}$} & $\leq 20$ & $93(24.8)$ \\
\hline & $21-39$ & $192(51.2)$ \\
\hline & $\geq 40$ & $90(24)$ \\
\hline \multirow{2}{*}{ Marital status } & Unmarried & $83(22.1)$ \\
\hline & Married & 292(77.9) \\
\hline \multirow{2}{*}{ Religion } & Hindu & $365(97.3)$ \\
\hline & Muslim & $10(2.7)$ \\
\hline \multirow{4}{*}{ Education } & PUC & $18(4.8)$ \\
\hline & High school & $57(15.2)$ \\
\hline & Primary school & $65(17.3)$ \\
\hline & Illiterate & $235(62.7)$ \\
\hline \multirow{6}{*}{ State of Origin } & $\begin{array}{l}\text { Andhra } \\
\text { Pradesh }\end{array}$ & $127(33.87)$ \\
\hline & West Bengal & $67(17.87)$ \\
\hline & Orissa & $39(10.4)$ \\
\hline & Madhya Pradesh & $37(9.87)$ \\
\hline & Bihar & $34(9.06)$ \\
\hline & Others & 71(18.93) \\
\hline \multirow{4}{*}{$\begin{array}{l}\text { Socioeconomic } \\
\text { Status }\end{array}$} & lower lower & $108(28.8)$ \\
\hline & upper lower & $185(49.3)$ \\
\hline & lower middle & $72(19.2)$ \\
\hline & upper middle & $10(2.7)$ \\
\hline
\end{tabular}

Smoking pattern: The overall proportion of smokers was $35 \%$ nearly two third. $85.6 \%$ smokers were smoking bidi (hand rolled). The mean age of initiation of smoking was 20.35 years and duration of smoking was 12.46 years. Among smokers $97 \%$ were smoking every day and mean money spent for smoking per week was 120.69 rupees. $46 \%$ of smokers had intention to quit smoking and majority quoted health problems as a reason for their intention to quit (82\%). Among those who had no intention to quit smoking (54\%) majority quoted the reason as addiction $(67.2 \%)$ (Table 2$)$. 
Table 2: Smoking pattern of the study subjects.

\begin{tabular}{|c|c|c|}
\hline Parameter & Subcategory & $\begin{array}{l}\text { No. of workers } \\
(\%)\end{array}$ \\
\hline \multirow{2}{*}{$\begin{array}{l}\text { Smoking } \\
(\mathrm{N}=375)\end{array}$} & Yes & $131(35)$ \\
\hline & No & $244(65)$ \\
\hline \multirow{3}{*}{$\begin{array}{l}\text { Type of smoking } \\
(\mathrm{N}=131)\end{array}$} & Bidi & $112(85.5)$ \\
\hline & Cigarette & $7(5.3)$ \\
\hline & Both & $12(9.2)$ \\
\hline \multirow{2}{*}{$\begin{array}{l}\text { Intention to quit } \\
\text { smoking } \\
(\mathrm{N}=131)\end{array}$} & Yes & $60(45.8)$ \\
\hline & No & $71(54.2)$ \\
\hline \multirow{3}{*}{$\begin{array}{l}\text { Reason to quit } \\
\text { smoking } \\
(\mathrm{N}=60)\end{array}$} & Health problems & $49(81.7)$ \\
\hline & Lack of money & $9(15)$ \\
\hline & $\begin{array}{l}\text { Friends and } \\
\text { family }\end{array}$ & $2(3.3)$ \\
\hline \multirow{4}{*}{$\begin{array}{l}\text { Reason for no } \\
\text { intention to quit } \\
\text { smoking } \\
(\mathrm{N}=71)\end{array}$} & Addicted & $47(66.2)$ \\
\hline & Pleasure & $11(15.5)$ \\
\hline & Working env & $4(5.6)$ \\
\hline & Not interested & $9(12.7)$ \\
\hline
\end{tabular}

The main reason for initiation of smoking was peer pressure which was followed by without any specific reasons, relief from work tension (Table 3).

Table 3: Factors affecting initiation of smoking.

\begin{tabular}{|ll|l|}
\hline Reason for first use & Frequency & Percentage \\
\hline $\begin{array}{l}\text { Company of friends/ } \\
\text { Peer pressure }\end{array}$ & 48 & 36.6 \\
\hline Relief from work tension & 29 & 22.1 \\
\hline To keep myself awake & 3 & 2.3 \\
\hline Family tension & 3 & 2.3 \\
\hline Family H/O & 1 & 0.8 \\
\hline Curiosity & 4 & 3.1 \\
\hline $\begin{array}{l}\text { Increase my work } \\
\text { performance }\end{array}$ & 1 & 0.8 \\
\hline Influenced by movies & 1 & 0.8 \\
\hline $\begin{array}{l}\text { Without any specific } \\
\text { reasons }\end{array}$ & 41 & 31.3 \\
\hline Others & 1 & 0.8 \\
\hline Total & 131 & 100 \\
\hline
\end{tabular}

Table 4: Determinants of smoking among study subjects.

\begin{tabular}{|c|c|c|c|c|c|}
\hline \multirow{2}{*}{ Parameter } & \multirow{2}{*}{ Sub category } & \multicolumn{2}{|l|}{ Smoking } & \multirow{2}{*}{$\begin{array}{l}\text { Chi square } \\
\text { value }\end{array}$} & \multirow{2}{*}{ p value } \\
\hline & & Yes & No & & \\
\hline \multirow{3}{*}{ Age group } & $\leq 20$ & $16(17.2 \%)$ & $77(82.8 \%)$ & \multirow{3}{*}{20.925} & \multirow{3}{*}{$\mathrm{p}<0.001^{*}$} \\
\hline & $21-39$ & $71(37 \%)$ & $121(63 \%)$ & & \\
\hline & $\geq 40$ & $44(48.9 \%)$ & $46(51.1 \%)$ & & \\
\hline \multirow{2}{*}{ Marital status } & Unmarried & $21(25.3 \%)$ & $62(74.7 \%)$ & \multirow{2}{*}{4.351} & \multirow{2}{*}{$0.037 *$} \\
\hline & Married & $110(37.7 \%)$ & $182(62.3 \%)$ & & \\
\hline \multirow{4}{*}{ Education } & PUC & $6(33.3 \%)$ & $12(66.7 \%)$ & \multirow{4}{*}{0.463} & \multirow{4}{*}{0.927} \\
\hline & High school & $19(33.3 \%)$ & $38(66.7 \%)$ & & \\
\hline & Primary school & $25(38.5 \%)$ & $40(61.5 \%)$ & & \\
\hline & Illiterate & $81(34.5 \%)$ & $154(65.5 \%)$ & & \\
\hline \multirow{4}{*}{$\begin{array}{l}\text { Socio Economic } \\
\text { Status }\end{array}$} & Lower lower & $51(47.2 \%)$ & $57(52.8 \%)$ & \multirow{4}{*}{10.786} & \multirow{4}{*}{$0.013^{*}$} \\
\hline & Upper lower & $53(28.6 \%)$ & $132(71.4 \%)$ & & \\
\hline & Lower middle & $23(31.9 \%)$ & $49(68.1 \%)$ & & \\
\hline & Upper middle & $4(40 \%)$ & $6(60 \%)$ & & \\
\hline \multirow{2}{*}{ Night shift } & Yes & $31(40.8 \%)$ & $45(59.2 \%)$ & \multirow{2}{*}{1.438} & \multirow{2}{*}{0.230} \\
\hline & No & $100(33.4 \%)$ & $199(66.6 \%)$ & & \\
\hline \multirow{2}{*}{ Working hours } & $<8$ & $11(24.4 \%)$ & $34(75.6 \%)$ & \multirow{2}{*}{2.475} & \multirow{2}{*}{0.116} \\
\hline & $>8$ & $120(36.4 \%)$ & $210(63.6 \%)$ & & \\
\hline \multirow{5}{*}{$\begin{array}{l}\text { Years as migrant } \\
\text { worker }\end{array}$} & $<5$ & $67(27.3 \%)$ & $178(72.7 \%)$ & \multirow{5}{*}{21.932} & \multirow{5}{*}{$\mathrm{p}<0.001 *$} \\
\hline & $6-10$ & $29(42.0 \%)$ & $40(58.0 \%)$ & & \\
\hline & $11-15$ & $7(50.0 \%)$ & $7(50.0 \%)$ & & \\
\hline & $16-20$ & $22(57.9 \%)$ & $16(42.1 \%)$ & & \\
\hline & $>20$ & $6(66.7 \%)$ & $3(33.3 \%)$ & & \\
\hline
\end{tabular}

Significant association was found between tobacco use and socio-economic parameters such as age group, marital and socio economic status. The tobacco use was significantly more in more than 40 years of age $(p<0.001)$. The tobacco use was significantly more in the married workers $(\mathrm{p}=0.037)$. Those who are of lower socio 
economic status had significantly higher prevalence of smoking ( $p=0.013)$.It was also found that workers who were migrants for more than 20 years had significantly higher proportions of smokers $(\mathrm{p}<0.001)$ (Table 4).

\section{DISCUSSION}

It is clear from this cross-sectional study that smoking is highly prevalent among construction workers. The reasons underlying this may be low socio economic status, occupation involving hard labour and poverty coupled with ignorance. Several studies have documented a positive relationship between tobacco consumption and low socioeconomic status. One major factor for heavy tobacco use in this group may be the fact that they were doing night shift work. The educational level of the construction workers was found to be very low. Consistent with earlier studies, this study found that lower the education, higher the prevalence of tobacco consumption, while overall tobacco use falls as education level rises. NFHS (2005) showed that $77.8 \%$ of tobacco use is seen among illiterates as compared to $52.9 \%$ among literates. ${ }^{8}$ A study on smoking prevalence among men in Chennai (India) in 1997 showed that the highest rate is found among the illiterate population $(64 \%){ }^{11}$ Hence, education is an important factor to be considered in any tobacco control programme. According to NFHS-3 smoking tobacco use in Karnataka, among men is $27.9 \%$, $28.7 \%$ in rural and $26.7 \%$ in urban. In a prevalence survey of tobacco use in Karnataka and Uttar Pradesh, the overall prevalence of 'ever use' of any kind of tobacco was $29.6 \%$ in Karnataka and $34.6 \%$ in Uttar Pradesh. ${ }^{12}$ The average age at initiation of tobacco use was 20.87 years. Those who started with addiction are more common in the $11-20$ years $(53.7 \%)$ and $21-30$ years (38.6\%) age-groups. According to NFHS-3, 2007, increase in tobacco use was particularly large among young males aged 15-24 years and among low wealth index. ${ }^{8}$ This data reveals the failure of tobacco control programmes in the vulnerable section of the community.

Another study that was conducted amongst construction laborers in Mumbai, found that those who regularly consumed alcohol and tobacco were $14.65 \%$ and $50.48 \%$, respectively. ${ }^{13}$ Smoking of tobacco was found to be the most common type of this adverse habit in males while its chewing was found to be more common in females. ${ }^{14}$

Similarly, in another study that was conducted amongst migrant labourers, it was seen that only 1.45 per cent $(n=4)$ of the respondents had never ever smoked or consumed tobacco .Almost one third of the study population, that is, 33.09 per cent $(n=91)$ had started smoking at the age of 14 or 15 years while 28.36 per cent $(n=78)$ had started at 16 or 17 years. ${ }^{15}$

Tobacco use in India has been higher among males than among females in India. However, the male-female gap was lower in the case of use of smokeless tobacco. The use of smokeless tobacco was equally high among middle-aged and elderly males and females. This indicates that adult females in India were as vulnerable as males, and at a high risk of using smokeless tobacco, especially in the higher age groups. With an increase in age, the odds of using tobacco significantly increase in India. Elderly and middle-aged females had significantly higher odds of consuming every type of tobacco. Smoking and dual use of tobacco among males were more common in the younger and middle-aged adults. ${ }^{16}$ Age has been found to be an important determinant of tobacco use in earlier studies. ${ }^{17,18}$ Tobacco use was found more common among the uneducated people in the country. Education was one of the most important determinants of tobacco use irrespective of the type of use. Uneducated males and females in India were at a higher risk of using tobacco. This can often be attributed to less knowledge and awareness among the uneducated people. Being poor was significantly associated with a higher risk of use of smokeless tobacco among males, and use of smokeless tobacco and dual use of tobacco among females in India. The relation between these socioeconomic markers and tobacco consumption is similar to relations observed in developed countries and other studies done in previous decades in India. ${ }^{17,19}$

\section{CONCLUSION}

The proportion of smokers among migrant construction workers was $36.2 \%$.Significant determinants of smoking were those aged more than 40 years, those of lower socio economic status, those married and more than 20 years as a migrant worker.

\section{ACKNOWLEDGEMENTS}

The authors thank the Professor and Head department of Community Medicine Mysore Medical College and Research Centre, Mysore, Karnataka for their kind support. The authors are also grateful to authors/editors/ publishers of all those articles, journals and books from where the literature for this article has been reviewed and discussed. The authors are also thanks all the study subjects for their kind support.

Funding: No funding sources Conflict of interest: None declared

Ethical approval: The study was approved by the Institutional Ethics Committee

\section{REFERENCES}

1. Mathers C, Stevens G, Mascarenhas M Global Health Risks: Mortality and burden of disease attributable to selected major risks. Geneva: WHO 2009.

2. Jha P, Nugent R, Verguet S, Bloom D, Hum R Chronic disease prevention and control. Challenge Paper for the Copenhagen Consensus, 2012.

3. International Institute of Population Sciences (IIPS) Global Adult Tobacco Survey: India 2009-2010. 
New Delhi: Ministry of Health and Family Welfare, Government of India.

4. Shafey O, Dolwick S, Guindon GE. Tobacco control country profiles. 2nd ed. Atlanta, GA: American Cancer Society; 2003.

5. World Health Organization; Young people: health risks and solutions. Fact sheet $\mathrm{N}^{\circ} 345,2011$.

6. World Health Organization: WHO report on global tobacco epidemic MPOWER Package. Geneva: WHO. 2008:7-9.

7. John RM, Rao RK, Rao MG, Moore J, Deshpande RS, Sengupta J, et al. The Economics of Tobacco and Tobacco Taxation in India. Paris: International Union against Tuberculosis and Lung Disease, 2010.

8. John RM, Rao RK, Rao MG, Moore J, Deshpande RS, Sengupta J et al. The Economics of Tobacco and Tobacco Taxation in India. Paris: International Union against Tuberculosis and Lung Disease.

9. U. S. Department of Labor Bureau of Labor Statistics; 1996. Career Guide to Industries.

10. Payal S, Laad B, Adsul B, Chaturvedi RM, Shaikh M, Prevalence of Substance Abuse among Construction Workers. Indian journal of research. 2013;2(3):280-83.

11. Sinha DN, Gupta PC, Pednekar MS. Tobacco use in rural area of Bihar, India. Indian Journal of Community Medicine. 2003;28(4):167-70.

12. Chaudhry K, Prabhakar AK, Prabhakaran PS. Prevalence of tobacco use in Karnataka and UttarPradeshin India, 2001.
13. Adsul BB, Laad PS, Howal PV, Chaturvedi RM. Health problems among migrant construction workers: A unique public private partnership project. Indian J Occup Environ Med. 2011;15(1):29-32.

14. WHO; Chronic diseases and health promotion. Global school-based student health survey (GSHS) purpose and methodology.

15. Sekhon H, Minhas S; A study of tobacco use amongst migrant labourers in North India. International Journal of Innovative Research and Development, 2014;3(4):109-13.

16. Singh A, Ladusingh L Prevalence and Determinants of Tobacco Use in India: Evidence from Recent Global Adult Tobacco Survey Data, 2014.

17. Rani M, Bonu S, Jha P, Nguyen SN, Jamjoum L Tobacco use in India: Prevalence and predictors of smoking and chewing in a national cross sectional household survey. Tob Control, 2003.

18. Reddy KS, Gupta PC Report on tobacco control in India. New Delhi: Ministry of Health and Family Welfare, Government of India, 2004.

19. Subramanian SV, Nandy S, Kelly M, Gordon D, Davey Smith G, Patterns and distribution of tobacco consumption in India: cross sectional multilevel evidence from the 1998-9 National Family Health Survey. BMJ. 2004;328(7443):801-6.

Cite this article as: Amrutha AM, Karinagannanavar A, Ahmed M. Proportion of smokers and its determinants among migrant workers in Mysore, Karnataka, India. Int J Community Med Public Health 2016;3:856-60. 